\title{
TINJAUAN HUKUM ISLAM TENTANG PELAKSANAAN ZAKAT GAJI DI KALANGAN PEGAWAI PADA KANTOR KEMENTERIAN AGAMA KABUPATEN BOYOLALI
}

\author{
Wartini \\ Moh. Amin Choiri S \\ Universitas Nahdlatul Ulama Surakarta
}

\begin{abstract}
Abstrak
Tulisan ini bertujuan untuk mengetahui pelaksanaan zakat bagi pegawai kantor Kementerian Agama Kabupaten Boyolali; dan untuk mengetahui tinjauan hukum Islam tentang pelaksanaan zakat gaji di kalangan pegawai kantor Kementerian Agama Kabupaten Boyolali. Jenis penelitian ini adalah deskriptif analitik. Hasil penelitian menunjukkan pelaksanaan zakat bagi pegawai kantor Kementerian Agama Kabupaten Boyolali setiap bulan sekali. Artinya pengeluaran zakat itu setiap bulannya. Hal ini mengisyaratkan bahwa zakat gaji yang selama ini berjalan di Kantor Kementerian Agama Kabupaten Boyolali disamakan dengan zakat pertanian dalam masalah pengeluarannya dan yang lainnya disamakan dengan zakat uang karena jumlahnya sebesar 2,5\%. Tinjauan hukum Islam tentang pelaksanaan zakat gaji di kalangan pegawai kantor Kementerian Agama Kabupaten Boyolali yaitu tidak mewajibkan zakat gaji atau profesi. Alasannya, tidak pernah dipraktikkan pada masa Rasulullah atau masa-masa awal pemerintahan Islam dan tidak ditemukan nash yang sharih secara khusus.
\end{abstract}

Kata kunci: Zakat Gaji, Hukum Islam

\section{Abstract}

This article aims to find out the implementation of zakat for employees of the Office of the Ministry of Religious Affairs of Boyolali Regency and to find out the review of Islamic law on the performance of zakat salary among 
employees of the Office of the Ministry of Religious Affairs of Boyolali Regency. This research is descriptive of analytics. The study results showed the implementation of Zakat for Employees of the Office of the Ministry of Religious Affairs of Boyolali Regency every month. This means that the expenditure of zakat is every month. This indicates that the zakat salary running in the Office of the Ministry of Religious Affairs of Boyolali Regency is equated with agricultural zakat in its expenditure. Others are equated with zakat money because the amount is 2,5\%. Review of Islamic Law on the Implementation of Zakat Salary among Employees of the Office of the Ministry of Religious Affairs of Boyolali Regency, which does not require zakat salary or profession. The reason was never practiced in the time of the Prophet or the early days of Islamic rule, and there were no particular nash sharih found.

Keywords: Zakat Salary, Islamic Law

\section{A. PENDAHULUAN}

Pada pendahulan merupakan kesempatan anda untuk menarik perhatian pembaca. Pembaca merupakan penulis potensial yang akan mengutip artikel Anda. Pendahuluan memberikan informasi kepada pembaca untuk memahami kajian spesifik anda. Eksplorasi latar belakang artikel anda dan posisikan artikel anda berbeda dengan artikel lain walaupun dengan

Islam sebagai agama universal tidak hanya berisi ajaran mengenai hubungan manusia dengan Tuhannya yang berupa ibadah, tetapi juga mengatur hubungan manusia dengan manusia yang disebut mu'amalah. Mu'amalah merupakan kegiatan manusia yang berperan sebagai khalifah dimuka bumi, yang bertugas menghidupkan dan memakmurkan bumi dengan cara interaksi antar umat manusia, misalnya melalui kegiatan ekonomi.

Kegiatan ekonomi adalah kegiatan dalam upaya memudahkan manusia memenuhi kebutuhan hidupnya. Untuk memenuhi kebutuhan hidup tersebut, manusia senantiasa bertarung dengan kekuatan alam untuk mengeluarkan dari padanya makanan, minuman, pakaian dan tempat tinggal. Karena adanya berbagai macam kebutuhan, situasi dan lingkungan hidup yang berbeda-beda, maka terjadilah antara sesama warga masyarakat 
berbagai macam perhubungan (Mu'amalah). Untuk menjamin keselamatan, kemakmuran, dan kesejahteraan hidup di dunia maupun di akhirat, Islam mengatur mu'amalah tersebut dalam sebuah sistem ekonomi yang berlandaskan kepada Al-Qur'an dan Al-Hadits, yang menekankan kepada nilai-nilai keadilan dan keseimbangan. Dengan demikian Islam adalah agama yang memandang pentingnya keadilan demi terciptanya masyarakat yang adil, makmur, dan sejahtera.

Hal ini tercermin dari perhatiannya yang besar kepada kaum yang lemah, yaitu menjamin dan melindungi kehidupan mereka. Maka melalui sebuah wadah lembaga zakat orang yang mampu memberikan hartanya kepada yang berhak menerimanya, seperti fakir, miskin, yatim piatu, kaum dhu'afa dan lain sebagainya. Senada dengan hal tersebut, Masjfuk Zuhdi sebagaimana dikutip Abdul Halim mengatakan zakat adalah "ibadah amaliyah ijtima'iyyah (ibadah yang berkaitan dengan ekonomi keuangan dan kemasyarakatan dan merupakan salah satu dari lima rukun Islam yang mempunyai status dan fungsi yang penting dalam syari'at Islam".' Bagi orang yang mengeluarkan zakat, hati dan jiwanya akan menjadi bersih, sebagaimana firman Allah SWT dalam Al-Qur'an surat at-Taubah ayat 103.

Zakat yang dikeluarkan oleh para muzakki akan dapat membersihkan dan mensucikan hati manusia, tidak lagi mempunyai sifat yang tercela terhadap harta, seperti rakus dan kikir. ${ }^{2}$ Perintah wajib zakat turun di Madinah pada bulan syawal tahun kedua hijrah Nabi SAW. Kewajibannya terjadi setelah kewajiban puasa Ramadhan dan zakat fitrah. Zakat mulai diwajibkan di Madinah karena masyarakat Islam sudah mulai terbentuk, dan kewajiban ini dimaksudkan untuk membina masyarakat muslim, yakni sebagai bukti solidaritas sosial, dalam arti bahwa hanya orang kaya yang berzakat yang patut masuk dalam barisan kaum beriman. Adapun ketika umat Islam masih berada di Makkah, Allah SWT sudah menegaskan dalam Al-Qur'an tentang pembelanjaan harta yang belum dinamakan zakat, tetapi berupa kewajiban infaq, yaitu bagi mereka yang mempunyai kelebihan wajib membantu yang kekuraangan. Besarnya tidak dipastikan, tergantung kepada kerelaan masing-masing. Yang tentunya kerelaan itu berkaitan erat dengan

\footnotetext{
${ }^{1}$ Abdul Halim, Modul Fiqih Kelas IV, (Jakarta: Pustakawidya Utama, 2009), hal. 25.

${ }^{2}$ Ahmad Fauzi, Ensiklopedi Islam, (Jakarta: PT. Ichtiar Baru Van Hjoeve, 1994), hal. 224.
} 
kualitas iman yang bersangkutan. Senada dengan hal tersebut, Abdul Halim mengatakan:

“Sunah Nabi yang merupakan penjabaran Al Qur'an menyebutkan secara eksplisit 7 (tujuh) jenis harta benda yang wajib dizakati beserta keterangan tentang batas minimum harta yang wajib dizakati (nisab) dan jatuh tempo zakatnya, yakni: emas, perak, hasil tanaman dan buah-buahan, barang dagangan, ternak, hasil tambang, dan barang temuan (rikaz). Tetapi hal ini tidak berarti, bahwa selain tujuh jenis harta benda tersebut diatas tidak wajib dizakati."

Pentingnya menunaikan zakat, terutama karena perintah ini mangandung misi sosial, yang memiliki tujuan yang sangat jelas bagi kemaslahatan umat manusia. Tujuan dimaksud antara lain "untuk memecahkan problem kemiskinan, meratakan pendapatan, dan meningkatkan kesejahteraan umat dan negara. Tujuan luhur ini tidak akan terwujud apabila masyarakat muzakki tidak memiliki kesadaran untuk menunaikannya". ${ }^{4}$ Sebagaimana firman Allah dalam Al-Qur'an Surat AlBaqarah ayat 267. Begitu pentingnya perintah ini maka para fuqoha (ahli hukum Islam) telah menyepakati dilakukannya tindakan tegas pada mereka yang lalai membayar zakat yang diwajibkan. Sejarah Islam mencatat banyak kejadian dimana negara mengambil langkah tegas untuk melaksanakan pembayaran zakat.

Dalam rangka untuk memotivasi umat dalam melaksanakan ibadah yang mulia ini, maka di Kantor Kementerian Agama Kabupaten Boyolali telah dibentuk Badan Amil Zakat, Infak, Sadaqah (BAZIS). Sebagaimana umumnya BAZIS di tempat-tempat lain, BAZIS unit Kantor Kementerian Agama Kabupaten Boyolali dimaksudkan sebagai wadah pengelola, penerima, pengumpulan, penyaluran dan pendayagunaan zakat, infak dan sadaqah dalam rangka peningkatan kesejahteraan masyarakat sebagai wujud partisipasi umat Islam dalam pembangunan nasional.

BAZIS unit Kantor, Kementerian Agama Kabupaten Boyolali ini sifatnya terbatas untuk mengelola zakat, infak dan sadaqah dari segenap pejabat dan pegawai di lingkungan Kantor Kementerian Agama Kabupaten Boyolali sendiri, satu hal yang sangat memudahkan BAZIS ini adalah diberinya wewenang untuk secara rutin setiap bulan memotong gaji segenap

${ }^{3}$ Abdul Halim, Op.Cit., hal. 35.

${ }^{4}$ Ujang Mahadi, Jurnal Ilmiyah Madania, Transformasi Islam dan Kebudayaan, (Bengkulu: Pusat Pengkajian Islam dan Kebudayaan (PPIK), 2000), hal. 13. 
pejabat dan pegawai di lingkungan Kantor Kementerian Agama Kabupaten Boyolali sebagai dana yang harus dikelola. Adapun yang selama ini telah berjalan adalah dipotongnya masing-masing dari pegawai pada setiap bulannya. Sedangkan besarnya pemotongan itu disama ratakan sebanyak 2,5\% dari gaji yang diterima. Namun ini sifatnya adalah lebih kepada kesukarelaan dari masing-masing pegawai, karena memang pada Kantor Kementerian Agama Kabupaten Boyolali sebelum adanya peraturan mengenai pemotongan gaji yang digunakan sebagai zakat selalu mengadakan yang sifatnya lebih kepada pengajian-pengajian sebagai wahana sosialisasi dari pada kewajiban untuk mengeluarkan zakat dari gaji masing-masing pegawai.

Pelaksanaan zakat pada Kantor Kementerian Agama Kabupaten Boyolali pemotongannya disamaratakan yaitu sebesar 2,5\% dari gajinya. Dan itu dikenakan kepada semua pegawai, tidak memandang apakah gaji dari pegawai itu telah mencapai nisab atau tidak. Yang jelas setiap pegawai dipotong gajinya sebesar 2,5\% dan tentunya yang bersedia untuk mengeluarkan itu. Adapun yang berkeberatan tentunya tidak dipotong sebesar itu, hanya saja mereka tetap mengeluarkan sebesar kesanggupan dan keihlasan dari masing-masing pegawai, dan ini dikeluarkan sebagai sadaqah semata.

Zakat pada gaji yang selama ini berjalan di Kantor Kementerian Agama Kabupaten Boyolali adalah setiap bulan sekali. Artinya pengeluaran zakat itu setiap bulannya. Hal ini diqiyaskan kepada zakat pertanian, karena pertanian itu dikeluarkan zakatnya pada saat panen. Begitu juga dengan gaji, karena gaji menerimanya setiap bulannya, maka pengeluarannya adalah setiap bulan. Hal ini mengisyaratkan bahwa zakat gaji yang selama ini berjalan di Kantor Kementerian Agama Kabupaten Boyolali disamakan dengan zakat pertanian dalam masalah pengeluarannya dan yang lainnya disamakan dengan zakat uang karena jumlahnya sebesar 2,5\%. Namun sekali lagi tidak ada keterangan di sana mengenai batasan minimum seorang pegawai diwajibkan untuk mengelurkan zakat karena semuanya terkena kewajiban tanpa memandang jumlah gaji yang diperoleh.

Kesadaran merupakan kemampuan individu mengadakan hubungan dengan lingkungannya serta dengan dirinya sendiri melalui panca inderanya dan mengadakan pembatasan terhadap lingkungannya serta terhadap dirinya 
sendiri melalui perhatian. Sebagai manusia yang beriman dan bertaqwa pada Allah SWT, tentu tidak akan pernah terlepas dari ibadah. Selalu banyak kesempatan kita untuk melakukan ibadah kepada Allah dalam keadaan apapun, dimanapun dan kapanpun kita mau melakukan pasti banyak kesempatan. Baik itu ibadah secara langsung kepada Allah seperti sholat, puasa, zakat, naik haji, maupun kepada sesama umat manusia yang didalamnya berkaitan dengan masalah tolong menolong, muamalah, menepati janji, berkata jujur, berbuat baik pada kedua orang tua dan lain sebagainya.

Ibadah di dalam Islam tidak disyari'atkan untuk mempersempit atau mempersulit manusia, dan tidak pula untuk menjatuhkan mereka di dalam kesulitan. Akan tetapi ibadah itu disyari'atkan untuk berbagai hikmah yang agung, kemashlahatan besar yang tidak dapat dihitung jumlahnya. Pelaksanaan ibadah dalam Islam semua adalah mudah.

Senada dengan hal tersebut, sejati ibadah mempunyai keutamaan yaitu mensucikan jiwa dan membersihkannya dan mengangkatnya ke derajat tertinggi menuju kesempurnaan manusiawi. Bahwasanya manusia sangat membutuhkan ibadah melebihi segala-galanya, bahkan sangat darurat membutuhkannya. Karena manusia secara tabi'at adalah lemah, fakir (butuh) kepada Allah. Sebagaimana halnya jasad membutuhkan makanan dan minuman, demikian pula hati dan ruh memerlukan ibadah dan menghadap kepada Allah. Bahkan kebutuhan ruh manusia kepada ibadah itu lebih besar dari pada kebutuhan jasadnya kepada makanan dan minuman, karena sesungguhnya esensi dan subtansi hamba itu adalah hati dan ruhnya, keduanya tidak akan baik kecuali dengan menghadap (bertawajjuh) kepada Allah dengan beribadah. Maka jiwa tidak akan pernah merasakan kedamaian dan ketenteraman kecuali dengan dzikir dan beribadah kepada Allah. Sekalipun seseorang merasakan kelezatan atau kebahagiaan selain dari Allah, maka kelezatan dan kebahagiaan tersebut adalah semu, tidak akan lama, bahkan apa yang ia rasakan itu sama sekali tidak ada kelezatan dan kebahagiaannya.

Zakat adalah kewajiban yang dikenakan terhadap harta benda. Dari satu segi adalah ibadah dan dari segi yang lain merupakan kewajiban sosial. Maka bila kita lihat pandangan Islam mengenai ibadah dan masalah sosial, kita katakan bahwa zakat adalah kewajiban sosial yang bersifat ibadah. Dan 
karena dalam zakat terkandung makna ibadah, maka kepekaan rasa Islam mencegahnya untuk tidak zakat kepada kaum ahl al-zimmah (warga non muslim yang berdiam di negeri muslim) dan menggantikannya dengan jizyah saja, agar mereka dapat ikut serta dalam pembiayaan pemerintahan umum, tanpa mewajibkan mereka untuk melaksanakan zakat ibadah khas Islam, kecuali bila mereka memilih beribadah secara Islam.

Memajukan kesejahteraan umum merupakan salah satu tujuan nasional negara republik Indonesia yang diamanatkan dalam pembukaan Undang-undang Dasar 1945. Untuk mewujudkan tujuan nasional tersebut, bangsa Indonesia senantiasa melaksanakan pembangunan yang bersifat fisik materil dan spiritual, antara lain melalui pembangunan di bidang agama yang mencakup terciptanya suasana kehidupan beragama yang penuh keimanan dan ketakwaan terhadap Allah SWT, meningkatnya akhlak mulia, terwujudnya kerukunan hidup umat beragama yang dinamis sebagai landasan persatuan dan kesatuan bangsa dan meningkatnya peran serta masyarakat dalam pembangunan nasional. Guna mancapai tujuan tersebut perlu dilakukan berbagai upaya antara lain melalui dana zakat. Senada dengan hal tersebut, Jalaluddin Rahmat mengatakan zakat sebagai rukun Islam merupakan kewajiban setiap muslim untuk membayarnya dan diperuntukkan bagi mereka yang berhak menerimanya. Zakat merupakan fardu 'ain bagi orang-orang yang telah cukup syarat-syaratnya. Zakat diwajibkan di Madinah pada bulan syawal tahun kedua hijri. Pewajibannya terjadi setelah pewajiban puasa Ramadhan dan zakat fitrah. Tetapi zakat tidak diwajibkan atas para nabi. Pendapat ini disepakati para ulama karena zakat dimaksudkan sebagai penyucian untuk orang-orang yang berdosa, sedangkan para Nabi terbebas dari hal demikian. Lagi pula mereka mengemban titipan-titipan Allah disamping itu mereka tidak memiliki harta dan tidak diwarisi. ${ }^{5}$

Di dalam Al-Qur'an banyak terdapat ayat yang secara tegas memerintahkan pelaksanaan zakat. Perintah Allah SWT. tentang zakat tersebut seringkali beriringan dengan perintah shalat. Term zakat dalam AlQur'an ditemukan sebanyak 32 kali, 26 kali diantaranya disebut bersamaan dengan kata shalat. Hal ini mengisyaratkan bahwa kewajiban mengeluarkan zakat seperti halnya kewajiban mendirikan shalat merupakan salah satu

${ }^{5}$ Ibid., hal. 16. 
perintah yang sangat penting dan mendapat perhatian besar dalam ajaran Islam. Apabila kita perhatikan kedudukan zakat dan salat di dalam rangkarangka pemahaman Islam kita dapatkan bahwa kedua pokok ibadah ini sangat benar berdampingan. Dimana Allah menyebutkannya kebanyakan bersamaan dengan kata shalat.

Hal ini memberi pengertian dan menunjukkan kepada kesempurnaan perhubungan antara dua ibadah ini dalam hal keutamaannya dan kepentingannya, yang pertama zakat adalah seutama-utamanya ibadah amaliyah dan yang ke dua shalat adalah seutama-utamanya ibadah badaniyah. Maka oleh karena itulah kita tidak heran kalau seluruh para umat para ulama dari salaf dan kholaf menetapkan bahwa mengingkari hukum zakat yakni mengingkari wajibnya yang dapat menyebabkan dihukum kufur ke luar dari agama Islam.

Zakat dan shalat dalam Al-Qur'an dan Al-Hadist dijadikan sebagai perlambang keseluruhan ajaran Islam.Pelaksanaan shalat melambangkan baiknya hubungan seseorang dengan Tuhannya, sedangkan zakat adalah lambang harmonisnya hubungan antar sesama manusia. Oleh karena itu zakat dan shalat merupakan pilar-pilar berdirinya bangunan Islam. Jika keduanya hancur Islam sulit untuk bisa tetap bertahan.

Kesenjangan penghasilan rejeki dan mata pencaharian di kalangan manusia merupakan kenyataan yang tidak bisa dipungkiri. Hal ini dalam penyelesaiannya memerlukan campur tangan Allah SWT. Lalu diwajibkan bagi orang yang kaya untuk memberikan sebagian hartanya kepada kaum fakir miskin. Kewajiban zakat itu merupakan jalan yang paling utama untuk menyelesaikan kesanjangan sosial tersebut, juga bisa merealisasikan sifat gotong royong dan tanggung jawab sosial dikalangan masyarakat yang telah merasakan adanya manfaat adanya zakat tersebut. Zakat akan mencairkan sekaligus menghapus berbagai prasangka negatif yang terjadi akibat perbedaan sudut pandang dan persepsi dari kedua belah pihak dan berubah menjadi suatu hubungan saling percaya dan membentuk investasi komitmen dua arah secara mendalam.

Apabila berbicara tentang tujuan dan hikmah zakat maka sesungguhnya sangatlah luas sekali bak samudra yang tak diketahui kedalamannya. Islam adalah agama yang diturunkan bagi umat manusia memiliki ajaran yang sangat penting dan membawa manfaat yang sangat 
mendalam, diantaranya adalah zakat. Memang tak dapat diragukan lagi bahwa zakat merupakan suatu rukun dari rukun-rukun agama, suatu fardu dari fardu-fardu agama yang diperintahkan kepada kita untuk melaksanakannya. Apabila kita melihat macam-macam zakat dan waktu penunaiannya maka kita akan mengetahui bahwa Islam sesungguhnya hendak menjadikan orang-orang fakir dan miskin terbebas dari kesulitan hidup yang mereka hadapi.

Dalam negara Islam zakat dapat ditetapkan sebagai hal yang diwajibkan, bukan sebagai amal perorangan. Dengan zakat negara dapat menjamin setiap orang dari kaum muslimin yang kekurangan, sehingga setiap orang akan merasa kehidupan diri dan keluarganya terjamin dalam segala keadaan. Dengan zakat dapatlah dibayar hutang orang yang menanggung hutang, baik hutang yang dialaminya dalam dunia Perdagangan maupun dalam bidang lain. Yang penting bukanlah bentuk aturan ini melainkan ruhnya yang menumbuhkan rasa kesetia kawanan dan solidaritas di dalam hati.

Lebih dari itu bukanlah tujuan Islam dengan aturan zakatnya untuk mengumpulkan harta dan memenuhi kas saja dan bukan pula sekedar untuk menolong orang yang lemah dan yang mempunyai kebutuhan serta menolong mereka dari kejatuhannya saja akan tetapi tujuannya yang utama adalah agar manusia lebih tinggi nilainya dari pada harta, sehingga ia menjadi tuannya harta bukan menjadi budaknya. Maka kepentingan tujuan zakat terhadap si pemberi sama dengan kepentingannya terhadap si penerima. Di sinilah letak perbedaan kewajiban zakat dengan pajak-pajak yang diciptakan oleh manusia dimana hampir tidak memperhatikan si pemberi kecuali memandangnya sebagai sumber pemasukan bagi kas negara.

Di dalam Al-Qur'an terdapat banyak ayat yang memerintahkan dan menganjurkan umatnya untuk menunaikan zakat demikian pula halnya hadis nabi juga banyak yang memerintahkan dan menganjurkan umatnya untuk melaksanakan zakat, karena memang zakat memiliki tujuan dan hikmah yang sangat mendalam. Diantara tujuan dan hikmah zakat antara lain:

1. Kekayaan adalah nikmat dari Allah SWT kepada hambanya yang harus disyukuri. Mensyukuri nikmat itu dapat dengan ucapan $\mathrm{Al}$ hamdulillah dan dapat pula dengan menggunakan nikmat itu sesuai dengan perintah Allah Membayar zakat adalah 
diperintahkan oleh Allah, maka membayar zakat itu berarti mensyukuri nikmat. Nikmat yang disyukuri dijanjikan oleh Allah akan ditambah.

2. Kekayaan yang dikumpulkan oleh seseorang belum tentu dari hasil jerih payah dan keringat sendiri, tapi bisa juga dari hasil tenaga para buruh yang bekerja padanya. Misalnya seorang yang memiliki sepuluh hektar tanah dalam penggarapannya tentu memerlukan tenaga orang lain, maka pada waktu ia memetik hasil tanah itu, misalnya padi ia harus memberikan sebagian dari hasil tanah itu kepada mereka yang ikut menggarapnya sebagai zakat, meskipun mereka itu pada waktu bekerja telah mendapat upah, karena mereka bagaimanapun tergolong fakir miskin.

3. Manusia di dunia ini ditakdirkan oleh Allah SWT tidak sama keadaannya ada yang kaya dan ada yang miskin, ada yang kuat dan ada yang lemah. Ada yang pandai dan ada yang bodoh, ada yang berpangkat tinggi dan ada yang berpangkat rendah, begitulah selanjutnya. Oleh karena itu manusia tidak dapat hidup didunia ini sendiri, tapi harus bekerja sama, maka yang kuat harus menolong yang lemah, yang besar harus menolong yang kecil dan begitulah seterusnya.

4. Zakat adalah mendidik dan membiasakan orang menjadi pemurah. Tabiat manusia biasanya bersifat kikir. Agar tidak demikian ia diwajibkan membayar zakat sehingga akhirnya ia bisa memberikan sesuatu kepada orang lain yang artinya ia tidak kikir lagi.

5. Diantara pencuri atau perampok ada yang disebabkan karena kemiskinan. Keadaan yang serupa itu, jika mereka telah tertolong dengan adanya pembagian zakat kiranya mereka tidak akan mencuri atau merampok lagi. Dengan demikian pembagian zakat itu merupakan pengamanan negara.

6. Zakat adalah modal umat Islam untuk pembangunan dan memerangi kemelaratan dengan cara-cara yang lebih prinsipil. Zakat juga memiliki tujuan lain yaitu untuk meratakan pendapatan 
sebagai alternatif pemecahan masalah kemiskinan dan keadilan sosial.

7. Zakat mengandung arti suci tambah dan berkah. Orang yang mengeluarkan zakat jiwanya bersih dari sifat kikir, tamak, hartanya tidak kotor lagi karena hak orang lain telah disisihkan dan diberikan kepada yang berhak menerimanya. Harta yang dizakati itu juga membawa berkah dan tambah berkembang. Berkurang dalam pandangan manusia tetapi bertambah dalam pandangan Agama. ${ }^{6}$

\section{B. METODE PENELITIAN}

Penelitian ini adalah deskriptif analitik yaitu sebuah penelitian yang menggambarkan, menguraikan secara objektif yang diteliti dalam hal ini mengenai kadar, nisab dan haul Zakat Pada Gaji di Kantor Kementerian Agama Kabupaten Boyolali kemudian melakukan analisis terhadap pelaksanaan zakat tersebut. Dalam penelitian ini pendekatan yang dipergunakan adalah normatif, yaitu "pendekatan tentang suatu masalah yang diteliti berdasarkan nas-nas, pendapat-pendapat para ulama yang berkaitan dengan pembahasan. Data yang akan dicari dalam penelitian ini adalah bagaimana pelaksanaan zakat gaji yang dipraktikkan di Kantor Kementerian Agama Kabupaten Boyolali. Penyusun setelah mengumpulkan data-data akan terus menindak lanjuti dengan memeriksa data-data itu terutama dari segi kelengkapan, kejelasan dan kevalidan serta kesesuaian dengan tema pembahasan. Selanjutnya mengklasifikasi dan mensistemasi data-data dalam paparan yang direncanakan lalu diformulasikan. Setelah itu penyusun melakukan analisis lanjutan terhadap data-data yang telah diklasifikasi dan sistemasi dengan menggunakan kaedah-kaedah, teori-teori, konsep-konsep dan pendekatan yang sesuai sehingga diperoleh kesimpulan yang benar. Penelitian ini merupakan penelitian kualitatif. Penelitian dengan menggunakan pendekatan kualitatif lebih menekankan analisisnya pada proses penyimpulan induktif serta pada analisis terhadap dinamika hubungan antar fenomena yang diamati, dengan menggunakan logika ilmiah serta

${ }^{6}$ M. Ali Hasan, Zakat, Pajak, Asuransi san Lembaga Keuangan, (Jakarta: PT Raja Grafindo Persada, 1997), hal. 34. 
penekanannya adalah pada usaha menjawab pertanyaan penelitian melalui cara-cara berfikir formal dan argumentatif.

\section{HASIL DAN PEMBAHASAN}

Hasil dan pembahasan memaparkan hasil penelitian dan analisis yang diperoleh. Berbagai fakta serta fenomena penting dapat dijabarkan lebih lanjut pada bagian ini. Setelah itu, dilanjutkan dengan pembahasan secara mendalam dengan menyampaikan temuan serta kepioniran gagasan dan signifikasinya. Hasil berisi jawaban dari permasalahan penelitian secara kuantitatif dan/ atau kualitatif secara jelas, tepat, dan lengkap yang dapat menggunakan informasi dalam bentuk gambar/ grafik/ tabel/ uraian secara aktual.

\section{Latar Belakang Pelaksanaan Zakat Gaji di Kantor Kementerian Agama Kabupaten Boyolali}

Salah satu program Kantor Kementerian Agama Kabupaten Boyolali adalah meningkatkan kemudahan umat beragama dalam menjalankan ibadahnya, termasuk penyempurnaan kualitas pelaksanaan zakat dan pengolahannya. Sebenarnya banyak yang telah dilakukan Kantor Kementerian Agama Kabupaten Boyolali untuk menunjang kegiatan kemasyarakatan, misalnya adanya keputusan Direktur Jendral Bimbingan Masyarakat Islam dan Urusan Haji Nomor 19 tahun 1984 tentang Pengaturan Biaya Administrasi Gerakan Infak Seribu Rupiah dalam Bulan Ramadhan. Ini merupakan salah satu contoh peran Kantor Kementerian Agama Kabupaten Boyolali dalam menunjang kegiatan kemasyarakatan dan memperhatikan masyarakat yang kurang mampu.

Hal ini dapat dilihat dari peran Kantor Kementerian Agama Kabupaten Boyolali dengan ditandai terbentuknya BAZIS tingkat kabupaten Boyolali pada awal tahun 1996, dengan keputusan Gubernur Kepala Kabupaten Boyolali, Nomor 9 /KPTS 1996 Tanggal 12 januari 1996 tentang pengukuhan pengurus badan amil zakat, infak dan sadaqah (ZIS) di Kabupaten Boyolali. Dasar pokok dari pembentukn BAZIS tingkat Kabupaten Boyolali karena melihat bahwa salah satu potensi umat Islam yang dapat digali, 
dikembangkan dan didayagunakan dalam rangka ikut berpartisipasi dalam pembangunan nasional guna meningkatkan taraf hidup dan kesejahteraan masyarakat adalah dalam penyediaan dana pembangunan di bidang sosial keagamaan yang berupa zakat, infak, sadaqah (ZIS) dan merupakan alternatif pemecahan dalam memberantas kemiskinan yang masih menjadi masalah bangsa dan negara kita.

Dalam pelaksanaannya, maka dihimbau kepada segenap pegawai/karyawan/ABRI di Kabupaten Kabupaten Boyolali terutama yang beragama Islam sudah sepantasnya menjadikan contoh/tauladan bagi masyarakat dalam hal penunaian dan pengumpulan zakat, infak dan sadaqah. Akan tetapi perlu diingat bahwa, pada awalnya tidak ditetapkan secara langsung untuk menunaikan zakat dari gajinya sebabnya 2,5\%. Namun diberikan kebijaksanaan untuk mengeluarkan sebagian dari gajinya pada setiap bulannya sebagai infak yang harus dikeluarkan artinya pada awalnya ia berbentuk infak wajib yang dikeluarkan setiap bulan dan belum merupakan zakat.

Dalam pelaksanaan BAZIS ini adalah dengan cara memotong gaji setiap bulan seluruh pegawai di Kabupaten Boyolali terutama yang beragama Islam. Potongan itu ditetapkan besarnya menurut:

a. Jenis pangkat dan golongan sebagai berikut:

1) Golongan I sebesar : Rp. 250,-

2) Golongan II sebesar : Rp. 400,-

3) Golongan III sebesar : Rp. 600,-

4) Golongan IV sebessar : Rp. 1.000,-

b. Khusus pejabat struktural:

1) Eselon V sebesar $\quad$ :Rp. 1.000,-

2) Eselon IV sebesar : :Rp. 2.000,-

3) Eselon III sebesar : :Rp. 3.000,-

4) Eselon II sebesar $\quad$ : Rp. 4.000,-

5) Eselon I sebesar $\quad$ : Rp. 5.000,- 
c. Khusus pejabat/ pegawai yang memperoleh tunjangan fungsional sebesar:

1) 60.000 ,- kebawah setaraf dengan Eselon V : Rp. 1000,-

2) $61000,-\mathrm{s} / \mathrm{d} 100.000$,- setaraf dengan Eselon IV : 2.000,-

3) $101.000,-$ s/d 200.000 ,- setaraf dengan Eselon III : 3.000,-

4) $201.000,-$ s/d 500.000,- setaraf dengan Eselon II : 4.000,-

5) 500.000,- keatas setaraf dengan Eselon I : 5.000,-7

Untuk pengumpulan infak ini melalui bendahara gaji masingmasing. Dan untuk mensosialisasikan kepada segenap pejabat atau pegawai awalnya melalui pengajian-pengajian yang diadakan oleh Kanwil Kemenag, ataupun acara-acara lain yang serupa dengan itu seprti seminar-seminar, dialog keagamaan dan lain sebagainya. Akan tetapi dalam pelaksanaannya agak berbeda dengan apa yang tercantum dalam surat edaran diatas, karena sebagian besar dari para pegawai memberikan dana infak tersebut lebih dari apa yang tertera pada surat edaran dimaksud. Hal ini dimaksudkan agar segenap pejabat dan pegawai Kanwil Kementerian Agama sudah sepantasnya menjadi contoh/teladan bagi pegawai-pegawai lain dalam penunaian dan pengumpulan zakat, infak dan sadaqah, Untuk itu diharapkan agar segenap pejabat dan pegawai yang beragama Islam menunaikan ibadah zakat, infak atau sadaqah dari gaji yang diterima setiap bulannya.

Hal ini berdasarkan prinsip prinsip pengelolaan zakat, infak dan shadaqah yaitu sukarela. Dalam pemungutan dan pengumpulan ZIS, BAZIS harus senantiasa berdasarkan prinsip kesukarelaan dari mereka yang menyerahkan ZIS dan sekali-kali tidak boleh dipaksakan atau cara-cara yang dapat dianggap sebagai suatu pemaksaan. Oleh karena itu dalam hal pemungutan dan pengumpulan lebih diarahkan kepada motifasi yang bertujuan memberikan kesadaran kepada umat agar membayar kewajibannya berupa zakat, infak dan sadaqah.

${ }^{7}$ Dokumentasi Kantor Kementerian Agama Kabupaten Boyolali, disalin pada tanggal 20 Agustus 2016 
Dalam perjalanannya diantara pejabat dan pegawai Kantor Kementerian Agama Kabupaten Boyolali terkadang ada yang tidak mengeluarkan zakat dari gaji mereka sebulan ataupun dua bulan. Hal ini dikarenakan terkadang ada sebagian pegawai dan pejabat yang sangat membutuhkan dana secara mendadak untuk kebutuhan hidup mereka sehingga mereka berkeberatan untuk mengeluarkan zakat tersebut. Namun harus ada pemberitahuan sebelumnya kepada Ketua BAZIS Kantor Kementerian Agama Kabupaten Boyolali untuk tidak dipotong karena alasan-alasan tertentu yang selanjutnya disampaikan kepada bendahara BAZIS Kantor Wilayah Kementrian Agama.

Memperlancar perjalannya, maka Jajaran Kementerian Agama Kabupaten Boyolali melakukan pembinaan teknis kepada BAZIS yang ada di wilayah masing-masing berdasarkan Instruksi Menetri Agama Republik Indonesia Nomor 5 Tahun 1991 tentang Pedoman Pembinaan Teknis Badan Amil Zakat, Infak dan Sadaqah, dengan berpedoman kepada kebijaksanaan sebagai berikut:

a. Peningkatan kesadaran umat

Bahawa sebagian besar rakyat yang beragama Islam mempunyai potensi untuk memberikan peran yang positif bagi terwujudnya cita-cita nasional sejalan dengan semakin meningkat dan meluasnya pembangunan. Potensi itu antara lain dapat berwujud pelaksanaan zakat, infak dan sadaqah sebagai salah satu kelembagaan agama Islam yang ada di tengah masyarakat, potensi itu perlu digali dihimpun dan dikelola dengan meningkatkan kesadaran umat untuk mengamalkan ajaran agamanya.

b. Peningkatan iman dan taqwa

Pengamalan ajaran agama Islam dibidang zakat, infak dan sadaqah merupakan upaya peningkatan iman dan taqwa serta penyucian diri dan harta dari hal-hal yang mengurangi keberkatannya karena di dalamnya terkandung hak-hak orang lain. Dengan demikian diharapkan iman umat semakin kuat dan harta umat semakin bersih 
c. Pengembangan potensi umat

Potensi umat Islam Indonesia untuk berpartisipasi dalam pembangunan cukup besar. Karenanya perlu diarahkan agar potensi itu semakin berkembang dengan selalu berpedoman kepada ajaran agama Islam dan peraturan perundang-undangan yang berlaku.

d. Kepentingan umat dan kesejahteraan masyarakat.

Pengelolaan zakat, infak dan sadaqah (ZIS) diarahkan bagi sebesar-besarnya kepentingan umat dan kesejahteraan masyarakat dengan tidak meninggalkan ajaran agama Islam serta sesuai dengan tujuan pembangunan nasional. Semua unsur umat diharakpan terkoordinasi dalam BAZIS yang merupakan wadah pengelola pelaksanaan ZIS di semua tingkat pemerintahan. Dengan demikian akan memudahkan penentuan prioritas dalam program pembinaan.

\section{Mekanisme Pengumpulan Zakat Gaji di Kantor Kementerian Agama Kabupaten Boyolali}

Dalam usaha pengumpulan zakat gaji BAZIS unit Kantor Kementerian Agama Kabupaten Boyolali melakukan kampanye zakat. Kampanye dilakukan secara lisan dan tulisan baik langsung maupun tidak langsung. Kampanye berbentuk lisan dan langsung melalui berbagai forum pertemuan dan dalam bentuk tulisan melalui seruan zakat gaji. Pada surat edaran dilampiri formulir surat kuasa bagi pejabat dan pegawai yang bersedia menyerahkan zakatnya melalui BAZIS unit Kantor Kementerian Agama Kabupaten Boyolali.

Surat kuasa ini diberikan kepada kabag keuangan Kantor Kementerian Agama Kabupaten Boyolali. Mereka yang menyerahkan surat kuasa tersebut didaftar sebagai pemeberi zakat (muzakki). Dari segi teknis, pengumpulan zakat gaji kantor Kementerian Agama Kabupaten Boyolali cukup lancar karena zakat langsung dipotong oleh kabag keuangan. Gambaran pengolahan pemotongannya adalah diawali dengan memindahkan data pejabat atau pegawai yang beragama Islam beserta golongan dan jumlah gaji dari daftar gaji 
yang diterima ke daftar yang telah disiapkan dengan nama daftar penerimaan zakat infak shodaqoh karyawan Kantor Kementerian Agama Kabupaten Boyolali kemudian langkah selanjutnya tinggal memotong 2,5\% dari jumlah daftar gaji yang tertera dalam daftar tersebut bagi yang menguasakan sebesar itu sebagai zakat atau memotong Rp. 2.000, atau Rp. 3.000,- atau lebih besar dari itu bagi yang menguasakan untuk dipotong sebesar itu sebagai infak. Selanjutnya dari bagian keuangan ini, diserahkan kepada Bendahara BAZIS unit kantor Kementerian Agama Kabupaten Boyolali. Lalu untuk pengamanan dan penataan administrasi dan keuangan secara resmi dari yang terkumpul itu disimpan di Bank.

\section{Pendistribusian Zakat Gaji di Kantor Kementerian Agama Kabupaten Boyolali}

Untuk pendistribusia dana zakat yang telah terkumpul maka dikeluarkan Surat Edaran No 02/EDR/BAZIS/-UNIT/XI/2016 yang isinya, berdasarkan kepada hasil pertemuan pengurus BAZIS Kantor KementerianAgama Kabupaten Boyolali pada tanggal 8 Juli 2016 diantara keputusannya adalah menyepakati penyaluran zakat, infak sadaqah (ZIS) para pegawai Kantor Kementerian Agama Kabupaten Boyolali untuk: Anak yatim/piatu atau orang jompo kurang mampu, yang bertempat tinggal di sekitar tempat tinggal Pegawai Kantor Kementerian Agama Kabupaten Boyolali tiap pegawai memohonkan dua (dua) orang. Selain itu digunakan untuk kegiatan kemasyarakatan, misalnya bantuan pembuatan masjid atau semisalnya, penyembalihan hewan kurban, bantuan kepada yayasan, tolong menolong, bantuan modal usaha masyarakat penggeng Boyolali, bantuan kepada muallaf, musafir, siswa dan mahasiswa

Pada dasarnya pendistribusian zakat hanya diberikan kepada delapan asnaf saja sebagaimana yang tertera dalam Al-Qur'an yaitu: fakir, miskin, amil zakat, orang yang terlilit hutang, muallaf, fi sabilillah, ibn sabil. Akan tetapi pendistribusian dana zakat di atas sebagaimana yang sudah berjalan di Kantor Kementerian Agama Kabupaten Boyolali sudah menjadi kesepakatan para amil zakat, karena melihat permasalahan di lapangan yang begitu kompleknya, 
yang mau tidak mau harus ditunaikan dan diberi bantuan, maka diambilkanlah dari dana zakat yang sudah terkumpul tersebut.

Mengenai pemberian dan penyaluran zakat yang ada pada Kantor Kementerian Kabupaten Boyolali maka hal ini sesuai dengan ketentuan pendistribusian dana zakat, walaupun kebanyakan dari pengeluarannya adalah ditujukan kepada pembangunan masjid atau madrasah, karena memang masjid ataupun madrasah adalah tempat yang sangat dibutuhkan terutama bagi umat Islam. Karena memang yang sudah berjalan selama ini adalah melayani umat yang membutuhkan dan datang ke Kantor Kementerian Agama untuk meminta bantuan dana walaupun tidak semuanya dikabulkan $100 \%$. Akan tetapi selain itu, amil zakat memang berasengaja mencari orang yang membutuhkan bantuan seperti fakir dan miskin untuk diberikan haknya dari dana zakat yang terkumpul, dan ini biasanya dilakukan pada waktu-waktu tertentu yaitu pada bulan ramadhan misalnya.

\section{Penentuan Haul dan Nisab Zakat di Kantor Kementerian Agama Kabupaten Boyolali}

Kantor Kementerian Agama Kabupaten Boyolali mencanangkan tentang adanya kewajiban zakat sudah sejak tahun 1996, yang pada awalnya berbentuk infak dan sedekah saja yang bersifat sukarela semata dan jumlahnya pun relatif kecil, hanya berkisar Rp. 250,- s/d Rp. 5.000,-. Akan tetapi secara bertahap pelaksanaan itu berjalan dengan lancar, sehingga pada akhirnya keluarlah Undang-Undang tentang zakat pada tahun 1999. Yang ini berakibat adanya kewajiban untuk mengeluarkan zakat dari gaji masing-masing pegawai sebesar 2,5\%. Dalam masalah haul zakat, di Kantor Kementerian Agama Kabupaten Boyolali menarik zakat dari masing-masing pegawai pada setiap akhir bulannya dengan cara memotong gaji masing-masing pegawai, yang ini memang sudah menjadi kesepakatan dan aturan pada Kantor Kementerian Agama Kabupaten Boyolali. Sehingga dengan cara ini dapat mempermudah amil zakat untuk memungut zakat dari gaji masing-masing pegawai yang sealanjutnya dapat didistribusikan kepada yang berhak untuk menerimanya. Cara ini dilakukan karena membandingkan dengan zakat pertanian. Pada zakat pertanian, zakatnya dikeluarkan pada saat 
memanen, begitu juga dengan gaji mengeluarkan zakatnya adalah pada saat gajian. Sehingga dalam hal ini tidak disyaratkan adanya haul (cukup tahun).

Adapun masalah nisabnya, maka di Kantor Kementerian Agama Kabupaten Boyolali mengqiyaskannya dengan zakat pertanian pula yaitu sebesar $653 \mathrm{~kg}$ beras. Sehingga gaji pegawai yang seharusnya telah memiliki nilai sebesar $653 \mathrm{~kg}$ beras sudah berkewajiban untuk mengeluarkan zakat. Akan tetapi dalam praktiknya, pelaksanaan zakat dari gaji masing-masing pegawai dibebankan kepada seluruh pegawai tanpa memperhatikan golongan dan pendapatan masing-masing pegawai. Artinya setiap pegawai berkewajiban untuk mengeluarkan zakat dari gajinya. Namun kewajiban ini tidaklah mutlak sifatnya, akan tetapi ia tetap memperhatikan kesanggupan dan kelonggaran masing-masing pegawai.

Dalam hal ini ada pegawai yang telah mencapai nisab zakat sebesar $653 \mathrm{~kg}$ beras akan tetapi ia berkeberatan untuk mengeluarkan zakat karena alasan-alasan tertentu. Maka keberatan semacam ini tetap diberikan toleransi dari pengurus zakat yang ada pada Kantor Kementerian Agama Kabupaten Boyolali tetapi ia tetap mengeluarkan sebagian dari gajinya atas nama sadaqah dan bukan zakat karena jumlah pengeluarannya kurang dari 2,5\%. Namun sebaliknya ada sebagian pegawai yang penghasilannya belum mencapai nisab zakat, tetapi ia sudah mengeluarkan zakat dari gajinya sebesar 2,5\%. Hal ini dikarenakan kepedulian mereka yang sangat tinggi kepada umat dan juga sebagai suri tauladan bagi yang lainnya, karena Instasi terkait adalah Instasi yang berlabelkan Islam. Yang perlu diperhatikan di sini adalah terhadap pemotongan gaji tersebut di karenakan tidak memperhatikan sampainya nisab dari gaji yang diperoleh masing-masing pegawai, sehingga berakibat adanya pemotongan gaji untuk zakat kepada semua pegawai kecuali kepada mereka-mereka yang berkeberatan. 


\section{Analisis Pelaksanaan Zakat Bagi Pegawai Kantor Kementerian Agama Kabupaten Boyolali}

Zakat adalah ibadah yang berkaitan dengan ekonomi keuangan dan kemasyarakatan) dan merupakan salah satu dari lima rukun Islam yang mempunyai status dan fungsi yang penting dalam syari'at Islam. Perintah wajib zakat turun di Madinah pada bulan syawal tahun kedua hijrah Nabi SAW. Kewajibannya terjadi setelah kewajiban puasa Ramadhan dan zakat fitrah. Zakat mulai diwajibkan di Madinah karena masyarakat Islam sudah mulai terbentuk, dan kewajiban ini dimaksudkan untuk membina masyarakat muslim, yakni sebagai bukti solidaritas sosial, dalam arti bahwa hanya orang kaya yang berzakat yang patut masuk dalam barisan kaum beriman. Adapun ketika umat Islam masih berada di Makkah, Allah SWT sudah menegaskan dalam Al Qur'an tentang pembelanjaan harta yang belum dinamakan zakat, tetapi berupa kewajiban infaq, yaitu bagi mereka yang mempunyai kelebihan wajib membantu yang kekurangan. Besarnya tidak dipastikan, tergantung kepada kerelaan masing-masing. Yang tentunya kerelaan itu berkaitan erat dengan kualitas iman yang bersangkutan.

Zakat profesi adalah zakat yang dikeluarkan dari hasil usaha yang halal yang dapat mendatangkan hasil (uang) yang relatif banyak dengan cara yang mudah melalui suatu keahlian tertentu. Senada dengan hal tersebut berdasarkan wawancara dengan Ibu Siti Mahmudah, mengatakan bahwa:

"Dalam rangka untuk memotivasi umat dalam melaksanakan ibadah yang mulia ini, maka di kantor Wilayah Departemen Agama (Kanwil Depag) Kabupaten Boyolali telah dibentuk badan amil zakat, infak, sedekah dan (BAZIS). Sebagaimana umumnya BAZIS di tempat-tempat lain, BAZIS unit Kanwil Depag Kabupaten Boyolali dimaksudkan sebagai wadah pengelola, penerima, pengumpulan, penyaluran dan pendayagunaan zakat, infak dan sedekah dalam rangka peningkatan kesejahteraan masyarakat sebagai wujud partisipasi umat Islam dalam pembangunan nasional".

BAZIS Kantor Kementerian Agama Kabupaten Boyolali ini sifatnya terbatas untuk mengelola zakat, infak dan sedeqah dari segenap pejabat dan pegawai di lingkungan Kantor Wilayah Kementerian Agama Kabupaten Boyolali sendiri, satu hal yang sangat memudahkan BAZIS

${ }^{8}$ Wawancara dengan Ibu Siti Mahmudah, selaku Ketua BAZIS Kantor Kementrian Agama Kabupaten Boyolali, disalin pada tanggal 20 Agustus 2016. 
ini adalah diberinya wewenang untuk secara rutin setiap bulan memotong gaji segenap pejabat/ pegawai di lingkungan Kementerian Agama Kabupaten Boyolali sebagai dana yang harus dikelola. Adapun yang selama ini telah berjalan adalah dipotongnya masing-masing dari pegawai pada setiap bulannya. Sedangkan besarnya pemotongan itu disama ratakan sebanyak 2,5\% dari gaji yang diterima. Namun ini sifatnya adalah lebih kepada kesukarelaan dari masing-masing pegawai, karena memang pada Kantor Kementerian Agama Kabupaten Boyolali sebelum adanya peraturan mengenai pemotongan gaji yang digunakan sebagai zakat selalu mengadakan yang sifatnya lebih kepada pengajian-pengajian sebagai wahana sosialisasi dari pada kewajiban untuk mengeluarkan zakat dari gaji masing-masing pegawai.

Zakat pada gaji yang selama ini berjalan di Kantor Kementerian Agama Kabupaten Boyolali adalah setiap bulan sekali. Artinya pengeluaran zakat itu setiap bulannya. Hal ini diqiyaskan kepada zakat pertanian, karena pertanian itu dikeluarkan zakatnya pada saat panen. Begitu juga dengan gaji, karena gaji menerimanya setiap bulannya, maka pengeluarannya adalah setiap bulan. Hal ini mengisyaratkan bahwa zakat gaji yang selama ini berjalan di Kantor Kementerian Agama Kabupaten Boyolali disamakan dengan zakat pertanian dalam masalah pengeluarannya dan yang lainnya disamakan dengan zakat uang karena jumlahnya sebesar 2,5\%. Namun sekali lagi tidak ada keterangan di sana mengenai batasan minimum seorang pegawai diwajibkan untuk mengelurkan zakat karena semuanya terkena kewajiban tanpa memandang jumlah gaji yang diperoleh. Dalam masalah kadar zakat pada gaji, maka Ibu Siti Mahmudah, menyatakan bahwa:

"Kadar zakat pada gaji di Kantor Kementerian Agama Kabupaten Boyolali besarnya adalah 2,5\% yang mana dikiaskan pada zakat harta karena berbentuk uang, sehingga disamakan kadar zakatnya dengan zakat harta. Adapun pengeluarannya maka dikiaskan kepada zakat pertanian, karena pengeluarannya secara langsung setelah menerima uang tersebut tanpa dikurangi dengan kebutuhan sehari-hari”.

\section{Analisis Tinjauan Hukum Islam tentang Pelaksanaan Zakat Gaji di Kalangan Pegawai Kantor Kementerian Agama Kabupaten Boyolali}

Hukum zakat gaji atau jasa, penghasilan, profesi tidak bergeser dari dua macam pandangan ulama, yaitu antara wajib dan tidak wajib. 
Masing-masing golongan ulama memberi argumentasi yang berbeda. Jika ditelusuri yang menjadi puncak perbedaan pendapat pada zakat gaji, profesi, jasa atau penghasilan antara lain adalah pada syarat haul, apakah diqiyaskan kepada zakat emas atau diqiyaskan kepada zakat pertanian atau diqiyaskan kepada keduanya.

Senada tersebut, ada para Fuqoha yang menyatakan pendapatnya tentang hukum pelaksanaan zakat gaji yaitu sebagai berikut:

\section{a. Imam Syafi'i}

Imam Syafi'i sebagaimana dikutip Thalita mengatakan bahwa:

"Harta penghasilan itu tidak wajib zakat meskipun ia memiliki harta yang sudah cukup nisab. Tetapi ia mengecualikan anak-anak binatang piaraan, di mana anak-anak binatang itu tidak dikeluarkan zakatnya bersamaan dengan zakat induknya yang sudah mencapai nisab, dan bila belum mencapai nisab maka tidak wajib zakatnya".9

\section{b. Imam Malik}

Imam Malik sebagaimana dikutip Thalita berpendapat bahwa:

"Harta penghasilan tidak dikeluarkan zakatnya kecuali sampai penuh waktu setahun, baik harta tersebut sejenis dengan harta yang ia miliki atau tidak, kecuali jenis binatang piaraan. Karena orang yang memperoleh penghasilan berupa binatang piaraan bukan anaknya dan ia memiliki binatang piaraan yang sejenis dan sudah mencapai nisab, maka ia harus mengeluarkan zakat dari keseluruhan binatang itu apabila sudah genap satu tahun. Dan apabila kurang dari satu nisab, maka tidak wajib zakat”.

c. Abu Hanifah

Abu Hanifah sebagaimana dikutip Thalita mengatakan bahwa:

"Harta penghasilan itu dikeluarkan zakatnya bila mencapai masa setahun penuh pada pemiliknya, kecuali jika pemiliknya mempunyai harta sejenis yang harus dikeluarkan zakatnya yang untuk zakat harta penghasilan itu dikeluarkan pada permulaan tahun dengan syarat sudah mencapai nisab. Dengan demikian bila ia memperoleh penghasilan sedikit ataupun banyak, meski satu jam menjelang waktu setahun dari harta yang sejenis tiba, ia wajib mengeluarkan zakat penghasilannya itu bersamaan dengan pokok harta yang sejenis

${ }^{9}$ Wawancara dengan Ibu Siti Mahmudah, selaku Ketua BAZIS Kantor Kementrian Agama Kabupaten Boyolali, disalin pada tanggal 20 Agustus 2016. 
tersebut, meskipun berupa emas, perak, binatang piaraan atau yang lainnya."

Berdasarkan pendapat diatas, para ulama mazhab bukan menolak adanya zakat gaji juga bukan membolehkan untuk dipungut. Hanya saja tak pernah membahasnya secara rinci dalam kitab-kitab mereka. Masalahya karea hal itu belum menjadi sumber penghasilan utama dan sektor riel ketika itu. Para ulama mazhab lebih cenderung membahas sumber-sumber zakat yang disebut secara eksplisit di dalam nash, baik Alquran maupun hadis. Sumber zakat dimaksud, disebut zakat ittifaq artinya sumber zakat yang disepakati dan tak ada satupun ulama yang berselisih pendapat tentangnya. Mereka mencoba memahami dengan berbagai metode istimbath (menyimpulkan hukum, yang dikaitkan dengan kondisi sosio-ekonomi masa itu.

Sebagian ulama yang tidak mewajibkan zakat gaji atau profesi. Alasanny, tidak pernah dipraktikkan pada masa Rasulullah atau masamasa awal pemerintahan Islam dan tidak ditemukan nash yang sharih secara khusus. Namun pandangan ulama ini jarang ditemukan dalam literatur-literatur fiqh. Sebaliknya pandangan sebagian ulama yang lain lebih cenderung mewajibkan zakat gaji/ profesi dalam karya-karya mereka dengan melakukan berbagai cara istimbath. Untuk memperjelas status hukum tentang zakat gaji, penghasilan, profesi tersebut rasanya perlu kita rujuk kepada berbagai sumber baik klasik maupun kontemporer. Sebagaimana firman Allah dalam Al-Qur'an surat Az Dzariyat ayat 19

Landasan zakat profesi dianalogikan kepada dua sifat qiyas yaitu sebagai berikut:

a. "Pertama tentang waktu pembayaran diqiyaskan kepada zakat pertanian yaitu dibayarkan ketika mendapatkan hasilnya (panen).

b. Kedua nishab dan kadar zakatnya dianalogikan kepada zakat emas yaitu seharga 94 gram emas sedangkan kadar zakatnya sebesar 2,5 persen".

Menurut Yusuf Qardhawi, penghasilan gaji disebut sebagai malmustafad'. Seperti gaji pegawai, upah buruh, penghasilan dokter, pengacara, pemborong dan penghasilan modal di luar Perdagangan, 
penghasilan profesi dan lainnya, wajib dikenakan zakat dan tidak disyaratkan sampai setahun, akan tetapi dizakati pada waktu menerima pendapatan tersebut. Dari berbagai pendapat yang dikumpulkan Qardhawi, pendapat yang rajih (kuat) menurut beliau adalah: Wajib zakat gaji, penghasilan, profesi atau jasa ketika saat diterima tanpa memerlukan syarat haul.

Sebagian ulama memandang zakat gaji/perofesi dalam tiga hal. Pertama, tidak ada dalil zakat profesi, tetapi dianjurkan untuk menunaikannya. Kedua, wajib zakat profesi, dengan alasan untuk maslahah masyarakat. Ketiga, wajib zakat profesi, alasan nash Alquran (ummumul ayyah) dan ijtihad ulama. Jadi, dapat dipahami bahwa zakat, dikenakan atas suatu harta berdasarkan kepada dua kaidah. Pertama, berdasarkan nash qath'i dari Alquran dan hadis, sebagai sumber ittifaq, jelas dan terang). Kedua, tidak ada nash yang jelas, maka digunakan kaidah Qiyas, misalnya gaji/penghasilan diqiyaskan kepada emas, perak sebagai pendapatan dalam bentuk uang.

\section{KESIMPULAN}

Pelaksanaan Zakat Bagi Pegawai Kantor Kementerian Agama Kabupaten Boyolali setiap bulan sekali. Artinya pengeluaran zakat itu setiap bulannya. Hal ini mengisyaratkan bahwa zakat gaji yang selama ini berjalan di Kantor Kementerian Agama Kabupaten Boyolali disamakan dengan zakat pertanian dalam masalah pengeluarannya dan yang lainnya disamakan dengan zakat uang karena jumlahnya sebesar 2,5\%. Namun tidak ada keterangan di sana mengenai batasan minimum seorang pegawai diwajibkan untuk mengelurkan zakat karena semuanya terkena kewajiban tanpa memandang jumlah gaji yang diperoleh.

Tinjauan Hukum Islam Tentang Pelaksanaan Zakat Gaji di Kalangan Pegawai Kantor Kementerian Agama Kabupaten Boyolali yaitu tidak mewajibkan zakat gaji atau profesi. Alasannya, tidak pernah dipraktikkan pada masa Rasulullah atau masa-masa awal pemerintahan Islam dan tidak ditemukan nash yang sharih secara khusus. Namun pandangan ulama ini jarang ditemukan dalam literatur-literatur fiqh. Sebaliknya pandangan 
sebagian ulama yang lain lebih cenderung mewajibkan zakat gaji/profesi dalam karya-karya mereka dengan melakukan berbagai cara istinbat.

\section{REFERENSI}

Ahmad, Pengertian Zakat, http://www.dakwatuna.com/2008/09/08/923/ zakat-definisi-dan-tujuannya/\#axzz4MFZrR91Q, (Diakses pada tanggal 20 Agustus 2016)

Almaia, Pengertian Gaji, http://wikipns.com/definisi-gaji-dan-upah-danbedanya,(Diakses pada tanggal 13 Agustus 2016)

Al-Zuhaili, Wahbah, Zakat Kajian Berbagai Macam Mazhab, Bandung: PT. Remaja Rosdakarya, 1995.

Fauzi, Ahmad, Ensiklopedi Islam, Jakarta: PT. Ichtiar Baru Van Hjoeve, 1994.

Gayatri, Seluk Beluk Zakat, http://www.artikelsiana.com/2015/06/pengertianzakat-fitrah-syarat-waktu-zakat-fitrah.html, (Diakses pada tanggal 20 Agustus 2016)

Hadi, Sutrisno, Metodologi Research 3, Yogyakarta: Andi Ofset, 2004.

Halim, Abdul, Modul Fiqih Kelas IV, Jakarta: Pustakawidya Utama, 2009.

Hasan, M. Ali, Zakat, Pajak, Asuransi dan Lembaga Keuangan, Jakarta: PT Raja Grafindo Persada, 1997.

Mahadi, Ujang, Jurnal Ilmiyah Madania, Transformasi Islam dan Kebudayaan, Bengkulu: Pusat Pengkajian Islam dan Kebudayaan (PPIK), 2000.

Maia, Pengertian Hukum Islam, http://pusatbahasa.diknas.go.id/kbbi, (Diakses pada tanggal 20 Juni 2016)

Muhammad, Zakat Profesi: Wacana Pemikiran dalam Fiqih Kontemporer, Jakarta: Salemba Diniyah, 2002.

Muslim, Imam, Shohih Muslim Juz II, Semarang: Toha Putra, tt.

Poerwodarminta, W.J.S, Kamus Bahasa Indonesia, Jakarta: Balai Pustaka, 1982. 
Rahmat, Jalaluddin, Pengertian Zakat, Bandung: PT. Remaja Rosdakarya, 1995.

Ramayulis, Jalaludin, Pengantar Ilmu Jiwa Belajar, Jakarta:PT Kalam Mulia, 1987.

Shiddiqy, Teuku Muhammad Hasbi Ash, Pedoman Zakat, Semarang: PT Pustaka Rizki Putra, 1987.

Soenarjo, dkk, Al Qur'an dan Terjemahnya, Jakarta: Proyek pengadaan Kitab Suci Al Qur'an) Departemen Agama RI, 1971.

Walgito, Bimo, Bimbingan dan Penyuluhan di Sekolah, Yogyakarta: Yayasan Penerbit F. Psikologi UGM, 1989.

Zuhaili, Wahbah, At-Tafsir Al-Munir fi Al-'Akidah wa Asy-Syari'ah wa AlMinhaj, Beirut: Dar Al-Fikr, 1991. 